\title{
MIDAS
}

Museus e estudos interdisciplinares

\section{Current challenges for African cultural heritage: a case study of Guinea-Bissau}

Desafios atuais para o património cultural africano: um estudo de caso da GuinéBissau

\section{Ana Temudo}

\section{OpenEdition}

\section{Journals}

Edição electrónica

URL: https://journals.openedition.org/midas/2909

DOI: $10.4000 /$ midas.2909

ISSN: 2182-9543

Editora:

Alice Semedo, Paulo Simões Rodrigues, Pedro Casaleiro, Raquel Henriques da Silva, Ana Carvalho

\section{Refêrencia eletrónica}

Ana Temudo, "Current challenges for African cultural heritage: a case study of Guinea-Bissau», MIDAS [Online], 13 | 2021, posto online no dia 15 dezembro 2021, consultado no dia 04 março 2022. URL: http://journals.openedition.org/midas/2909 ; DOI: https://doi.org/10.4000/midas.2909

Este documento foi criado de forma automática no dia 4 março 2022.

\section{c) (†)(2)}

Midas is licensed under a Creative Commons Attribution-NonCommercial-ShareAlike 3.0 International License 


\section{Current challenges for African cultural heritage: a case study of Guinea-Bissau}

Desafios atuais para o património cultural africano: um estudo de caso da GuinéBissau

\section{Ana Temudo}

\section{NOTA DO EDITOR}

Artigo recebido a 30.01.2021

Aprovado para publicação a 12.07.2021

\section{Introduction}

1 In $21^{\text {st }}$ century museums, in the former metropolis of African colonies the place of African heritage is becoming an increasingly salient issue. How museums should display African cultural material is a question that is framed by a general concern with the role of museums and cultural heritage in civil society, when societies are increasingly multicultural and economically segmented, and by the level of access to formal education. Museums are now driven by the desire for democratization and inclusion. For museums in former colonial metropolises, inclusion and democracy involve building bridges with populations of African origin. This type of action emerges from a growing focus on pluralism, participation, minority representation of nonwestern cultures and the role of museums in civil society.

2 This orientation started in the 1980s (Karp and Lavine 1991; Karp, Kreamer and Lavine 1992; Karp et al. 2006) with the effects of globalization that brought about new museological practices, encouraging debates related to negotiation and community 
management in museums, promoting the creation of transnational communities and generating cooperation, collaboration and sharing movements that have highlighted the power of cultural heritage as an agent of sustainable development, and the museum as a space for negotiating ownership (Golding and Modest 2013; Silverman 2014; Basu and Modest 2015).

The achievements of including communities in museums are reflected in the way recent studies address the issue of heritage restitution, from provenance research and collaborative knowledge creation processes that attempt to review colonial categories based on information sharing with communities of origin (Grimme 2020; Schorch 2020; Weber-Sinn and Ivanov 2020). However, these are still one-off studies, and the issue of return of cultural heritage is mainly addressed from a legal and political perspective (Tyathacott and Arvanitis 2014). Sarr and Savoy (2018) argue that the restitution of heritage should start from a system of "relational ethics" that uses heritage as a means for the reconstruction and reformulation of the history and memory of the African continent «through reconnecting these objects with the current societies and the questions and problems that these contemporary societies pose» (Sarr and Savoy 2018, 32).

4 In parallel, post-colonial studies argue that African museums emerge from systems of colonial governance that have implemented physical and conceptual structures that have enabled the development of heritage projects created to fulfil a symbolic and material desire for power (Arinze 1998; Adedze 2002; Edwards, Gosden and Philips 2006; Peterson, Gavua and Rassol 2015). Some authors also claim that even after independence, and despite their "Africanization" achieved with the help of international organizations such as UNESCO (Myles 1976; Abungu 2005), these institutions have continued to promote the production of an official past through heritage technologies that privilege certain memories and repress others (Jong and Rowlands 2010).

This article analyses the different perspectives from which issues of restitution of nonEuropean cultural heritage have been approached internationally and in the Portuguese context. This analysis helps understand how the problem is experienced in Africa. I exemplify this experience with the museological reality of Guinea-Bissau, namely through the history of its National Ethnographic Museum.

\section{Cultural heritage and restitution: the international scene}

6 Tythacott and Arvanitis assert that restitution is «a highly charged, political subject, entangled within shifting power relations between, and within countries» $(2014,2)$. Basu defines the act of restitution as a diasporic movement of cultural heritage defending that the «dominant postcolonial response should be to demand restitution in form of repatriation» $(2011,37)$ if objects are seen from the countries of origin as victims of forced displacement by colonialism. To clarify the difference between restitution and repatriation movements, the organization Collections Trust briefly summarizes restitution as «the process by which cultural objects are returned to an individual or community. Repatriation [on the other hand] is the process by which 
cultural objects are returned to a nation or state at the request of a government» (Collections Trust 2020).

7 During colonial times the despoliation of cultural goods was a widespread and systematic practice, not only associated with scenarios of war and military occupation. In general, the colonization of African, Asian and South American territories resulted in the dispersion of this cultural heritage into Western collections. Today, trafficking in cultural goods constitutes a global industry, although it is controlled at the national level (with the application of restrictive laws against theft and illicit trafficking) and at the international level through the action of organizations such as the International Council of Museums (ICOM), the UNESCO, and the International Criminal Police Organization (INTERPOL). The media also serve to raise public awareness (UNESCO 2001). Of all these bodies, UNESCO's action in protecting heritage at risk stands out, ensuring that State Members that have lost certain cultural objects of fundamental importance and wish them returned - if international conventions cannot be applied may request them from the Intergovernmental Committee for Promoting the Return of Cultural Property to its Countries of Origin or its Return in Case of Illicit Appropriation (ICPRCP) established in 1978.

8 Amadou-Mahtar M'Bow, general director of UNESCO from 1974 until 1987, wrote in 1978:

The return of a work of art or record to the country which created it enables a people to recover part of its memory and identity and proves that the dialogue between civilizations which shapes the history of the world still continuing in an atmosphere of mutual respect between nations. (M'Bow 1978, n.p.)

Examples of these prior agreements are the Convention for the Protection of Cultural Property in the Event of Armed Conflict (UNESCO 1954) and the Convention on the Means of Prohibiting and Preventing the Illicit Import, Export and Transfer of Ownership of Cultural Property (UNESCO 1970), which marked key moments and defined the existence of preventive measures and procedures for the restitution of heritage, as well as a dynamic of cooperation between countries.

In 1995 the UNIDROIT Convention on Stolen or Illegally Exported Cultural Objects (UNIDROIT 1995) was created as an instrument drawn up at the request of UNESCO to develop a uniform minimum corpus of rules of private law relating to the international trade of art. The 1995 UNIDROIT Convention is a complementary instrument to supplement the provisions of public law contained in UNESCO's 1970 Convention (UNESCO 1970).

11 In 2002, the directors of 18 European and American art museums signed the Declaration on the Importance and Value of the Universal Museums. This declaration was an important moment in which the international museum community «share[d] the conviction that illegal traffic in archaeological, artistic, and ethnic objects must be firmly discouraged» (Declaration on the Importance and Value of Universal Museums 2004, 4).

12 The ICOM Code of Ethics, unanimously adopted by the $15^{\text {th }}$ ICOM General Assembly held in Buenos Aires (Argentina) on the $4^{\text {th }}$ of November 1986, and revised in 2001 and 2004, relates to the origin of the collections, considering the principle of cooperation as a means of establishing partnerships with countries, which - for various reasons - have lost a significant part of their heritage. With this document, ICOM also asserts, regarding the restitution of cultural property: 
Museums should be prepared to initiate dialogue for the return of cultural property to a country or people of origin [...] based on scientific, professional or humanitarian principles, as well as applicable local, national and international legislation, in preference to action at governmental or political level. (ICOM [2004] 2017, 6.3, p. 33)

Countries like France, Germany and the Netherlands, and to a lesser extent the UK, are seriously engaged in the project of restitution/repatriation as testified by the international public debate initiated in 2018 with the publication of the report on the restitution of African heritage by the French government (Sarr and Savoy 2018). This effort entails knowing exactly how many and what artifacts from Africa their museums have, coupled with a clear understanding of how such objects were acquired. For the authors of the report, the Senegalese economist and writer Felwine Sarr and the art historian Bénédicte Savoy «the act or gesture of restitution should not be considered as a dangerous action of identarian assignation or as the territorial separation or isolationism of cultural property» $(2018,2)$. Despite publicly positioning himself in favour of the restitution of objects to their countries of origin, the Cameroonian philosopher, Achille Mbembe (2020), disagrees with Sarr and Savoy (2018) arguing that very few countries are really concerned with understanding what originally justified their presence in Europe and what they meant within European consciousness. He asks himself what precisely we [Europeans] want to get rid of; what we are trying to repatriate and why; and whether the work these objects were meant to do in the history of European consciousness is complete. After so many years of the presence of these objects within its institutions, Mbembe questions whether Europe has finally learned to deal with what comes from outside $(2020,354)$. The Senegalese philosopher Souleymane Bachir Diagne agrees with Mbembe. In his view:

[...] restitution cannot be simply a return to the kingdom following exile. It must draw on the wealth of new energies and meanings which the objects in question have produced in the art world and will continue to produce after their return, to emphasize that the time has come to reinvent the museum as a realization of networks and synergies. (Diagne 2021, n.p.)

These authors make us think about objects as permeable structures of meaning. Shouldn't we ask ourselves if it wouldn't be better to make the museum collections circulate between continents, different institutions, and communities instead of being circumscribed to a single geographical area?

Following the position taken by the French government, the ministers of culture of 16 German states met in March 2019 to draw up a joint declaration on the maintenance of colonial collections. The German Museums Association $(2021,10)$ believes «that the colonial past of museums and their collections [should] be reappraised» based on three main principles: provenance research, transparency through digitalization and public access, and collaboration with communities of origin.

In England this issue is still awaiting resolution, seen for the time being from actions to decolonize the collections of different museums (Hickley 2020).

Dutch museums are sending scholars to the former colonies while developing guidelines to deal with complaints for the return of heritage (Hickley 2019), as in the example of Tropenmuseum, that had already established the principles and process for the return of objects to countries of origin (NMVW 2019).

18 Around the world there are several research projects that have been dealing with the colonial past. Focusing on recent examples, it's worth noting the Museums Lab, that 
started in 2021, in Berlin, as «a platform for joint learning, exchange and continuing education regarding the future of museums in Africa and Germany» (Museums Lab 2021, n.p.). Another relevant project is the European project "Taking Care Ethnographic and World Cultures Museums as Spaces of Care" that, since 2019, «explore[s] under-tapped potential of these [ethnographic and world culture] museums, for thinking critically about planetary pasts and about sustainable, convivial futures» and focuses «on questions related to the unequal sharing of heritage resources and restitution» (Taking Care Project 2021, n.p.).

\section{Portugal's positioning on cultural heritage restitution actions} other heritage structures, replacing former governmental bodies in the area of museums and heritage. In what concerns restitution issues, the newly created Department for Cultural Assets (Departamento de Bens Culturais) (Ordinance n.o 223/2012), has the following responsibilities within the DGPC:

Monitor the issues related to the return of movable cultural objects between States of the European Union or of other States under conditions of reciprocity and, within that framework, to rule on requests for return in accordance with the law. (art. 2.., \& 5.․, f) Misters n. $.35 / 2019$ approved the creation of the Future Museums Project Group. The main objective assigned to the Project Group was the responsibility to «design and propose the instruments necessary for the implementation of management models» ( $\S$ 2., a, 1273), which shaped the whole project (2019-2020) and the interaction between the five axes that the research and reflection was based upon: management of museums, palaces and monuments; networks and partnerships; digital transformation; collection management; and audience engagement (Camacho 2021, 7). The theme of heritage restitution is not explored in the Project Group final report, stressing that «patronage, internationalization and disincorporation [are] topics whose complexity would require more time and other means to enable more consistency with these matters» (Camacho 2021, 96). However, the Report also acknowledges that 
disincorporation «has gained public visibility and deserves an informed and dispassionate professional approach that promotes reflection (...) and guidelines arising from the tutelage [Ministry of Culture]» (Camacho 2021, 83).

In the field of social inclusion of museums, the Report only refers to the importance of «policies aimed at the diversification of audiences, aiming at increasing access and reducing social inequalities, not only among the population but also the immigrant» (Camacho 2021, 16). After a careful examination of this report, one can conclude that the themes addressed are not yet clearly listed in the Portuguese museums and heritage agenda and the question remains: will Portugal follow the lead of France, Germany and Netherlands?

In 2021, probably in view with the global movement around heritage restitution, ICOM Portugal (ICOM Portuguese National Committee) took a first step and launched a survey targeting public and private museums in order to identify the presence of heritage from non-European territories in Portuguese museums (ICOM Portugal 2021). The survey preliminary results reveal that only $30 \%$ of museums answered the survey due to the precariousness situation experienced by these institutions, e.g. the lack of specialized staff to carry out the necessary research on the provenance of their collections. $^{2}$

António Pinto Ribeiro, researcher and cultural programmer, ${ }^{3}$ exposed this deficiency in an interview back in 2018, in the wake of the publication of the French report SarrSavoy:

In Portugal, we have a very serious problem: there are no lists [of art pieces from the former colonies] either in relation to museums or archives. Many of these objects are in storage, not even on display. There could be 10 thousand, 50 thousand or 80 thousand. (Lusa 2018, n.p.)

In this article we argue that the theme of restitution is not in the Portuguese political agenda, in spite of recent developments and debates. In 2016, the former director of the National Museum of Ethnology (from 1993 to 2015), Joaquim Pais de Brito, recalled that the international debate around restitution «has been going on since the 1970s and is a problem with many dimensions» (Henriques 2016, n.p.). When asked about the topic, Pais de Brito seems to indorse a Eurocentric view on non-Western cultural heritage by advocating that Portuguese museums should:

[...] encourage that the countries requesting the return are plausible interlocutors and develop institutions with the skills, the conditions of security, conservation and quality that allow the return, and that important documents for humanity are not lost by a demagogic political correctness (...) the returns are placed from a request made by a country or an institution, which must include concrete objects and reasoned reasons. (Henriques 2016, n.p.)

Nevertheless, in 2020, the controversial proposal for the "decolonization of knowledge" from the deputy Joacine Katar Moreira, then supported by Partido Livre (left-wing political party), that was rejected by the Portuguese parliament, would draw attention to the topic of heritage restitution. The proposal suggested that all the heritage from the former colonies in the Portuguese territory should be returned to their countries of origin in order to decolonize state museums and monuments. The proposal was included in Partido Livre's electoral agenda and intended «that the heritage of the former Portuguese colonies, which is currently in the possession of national museums and archives, could be identified, claimed and returned to the communities of origin» (Lusa 2020, n.p). According to this proposal, the list of heritage to be returned would be 
drawn up by a "group composed of museologists, curators and researchers» that would contribute for the «re-contextualization of the collections of national museums and monuments» in order to "stimulate a vision of the colonial slave trade past, reframing it and re-contextualizing it in the light of academic research» (Lusa 2020, n.p).

This proposal inspired some debate in the national press. In response to the deputy's proposal, Paulo Costa, current director of the National Museum of Ethnology - MNE - in Lisbon) replied, in the press, that «each case must be examined in its specificity; nothing can be defined by decree» (Caetano 2020, n.p.). He also guaranteed that «no request has been made to Portugal or specifically to the [National] Museum of Ethnology for the return of cultural goods» (Caetano 2020, n.p.). For Costa it is necessary to distinguish «(...) works that have been removed by the application of force, i.e., the outcome of looting, and those that are considered to result from improper alienation (...)» (Caetano 2020, n.p.).

One may also consider that this is not only a matter of problematizing the restitution of heritage, but also the need to reflect about new ways of documenting and exhibiting this heritage. In this sense, as a response to how Portuguese museums should deal with their non-European collections in exhibition terms, during the seminar Descolonizar os Museus: Isto na Prática? (Decolonize Museums: This in Practice?) organized by the Portuguese association Acesso Cultura ${ }^{4}$ in 2019, Luís Raposo, president of ICOM Europe, drew attention to the need to:

[...] review museographic narratives, rebuild collections and build collections that speak on the theme of slavery, also extending approaches with the intervention of communities with different sensibilities, for a greater democratization of these spaces. (Lusa 2019, n.p.)

In short, the need and the importance for museums to revisit the Portuguese colonial past. However, such topic is not a new one in the museum context. Already back in 2010, Maria Manuela Cantinho Pereira, director of the Geographical Society of Lisbon, stressed the need to:

[...] re-evaluate the role of museums with colonial collections, drawing attention to the importance of this heritage in the reflection that citizens - Portuguese, Angolans, Mozambicans, all - can and should make on their past, their contemporaneity and the changes underway. (Pereira 2010,9)

31 Indeed, only a large investment in the study of these collections will then allow for a more informed debate. It is important to note that, regarding the Portuguese academic field, African heritage has mostly been addressed from the perspective of social memory (e.g., Henriques 2009; Domingos and Peralta 2013; Leite 2014). Occasional case studies on African cultural heritage collections in Portuguese museums can also be identified (e.g., Pereira 2005; Botas 2013).

\section{Cultural heritage in Africa}

In 1989 the Angolan writer Henrique Abranches compiled a set of texts portraying the museological and heritage panorama of African countries in the publication Identity and Cultural Heritage. Regarding the question of the return of heritage to countries of origin, he stated that, at that time, African countries «[...] have not yet decided to face the question of the return of cultural goods or are not yet seriously motivated to recover these goods» (Abranches 1989, 15). In his view, these countries were «better 
represented in museums in Europe and America than in their own land» (Abranches 1989, 20).

Abranches argues that in Africa there is «a total absence of the minimum conditions necessary for the conservation and preservation of material goods, whether those which have been returned to their country of origin or those from local collections» due to the state of general underdevelopment in Africa which aggravates the conditions for the return of the objects and implies the development of museums with the necessary conservation conditions (Abranches 1989, 31). He also notes that African countries lack legislation for the protection of cultural heritage and do not have a clear definition of the concept of cultural heritage, reality that can only be overcome through cooperation programs "with the most developed and progressive countries» (Abranches 1989, 32).

In this theme Abranches agrees with many other authors (e.g., Kusimba and Klehm 2013) defending the importance of international collaboration for the development of museums, exhibitions, and programs in Africa. By presenting these arguments, Abranches seems to agree with the western museum model inherited by African societies during colonialism and focused on the preservation of cultural evidence into the future. The author also seems to forget the international effort that took place during that decade (1980-1990), which culminated in the creation of museums in 16 West African countries. This initiative was due to the West African Museums Programme - WAMP (1982) and the International Council of African Museums AFRICOM (1991) that coincided with the global bureaucracies of world heritage and the new museology movement that questioned representation and community relations in museums (Kratz 2014).

Between the end of 1980 and the beginning of 2000 Portuguese-speaking countries also contributed to the improvement of postcolonial African museum projects. This was achieved through a series of conferences that worked as a «binder body of museums and related institutions in Portuguese-speaking countries (...) offering knowledge of museum collections and reflections on the objectives, means and actions of museums» (ICOM 1989, 5).

36 In 2009, AFRICOM recognized the gap in the inventory of African collections and published a manual of standards developed to enable the management of collections in museums hoping to promote the security of objects, the exchange between museums and the development of common projects (research, exhibitions, training). This project enabled the digitalization of inventories and documentation of collections by organizing standardized and accurate information. This manual encompasses all types of collections in both the humanities (history, archaeology, ethnography, art) and the natural sciences (palaeontology, zoology, geology) and it was tested with the collections of five pilot museums of Angola, Guinea-Bissau, Mozambique, Cape Verde and São Tomé and Principe (AFRICOM 2010,13). This measure is somehow aligned with the concern shown by Abranches two decades earlier when he stated that it was necessary to find measures that allowed the creation of an international inventory and information structure that would enable a planned and consented exchange (Abranches 1989, 25). 


\section{Museums and heritage in Guinea-Bissau: The National Ethnographic Museum unsettled history} path of the National Ethnographic Museum of Guinea-Bissau (MEN), the post-colonial heritage institution in the country, which inherited the memories as well as some material evidence of the colonial museum, Museu da Guiné Portuguesa (1945-1974). Guinea-Bissau was a Portuguese colony until 1974, and thus it is possible to find several examples of this country's cultural heritage even today in several Portuguese museums. ${ }^{5}$ However, in this article we will rather examine the steps taken by this post-colonial museum in the defence and safeguarding of Guinean heritage by going through several perspectives pointed out by a group of key actors during the Portuguese Speaking Museums Meetings, mentioned above and promoted by the national committees of ICOM of the Portuguese speaking countries, from the end of the 1980s until 2011, the date of the sixth and last meeting. These meetings were important for revealing the main questions that guided Guinean museology from the 1980's until the first decade of the $21^{\text {st }}$ century.

In 1989, at the second Portuguese Speaking Museums Meeting, and one year after the opening of the National Ethnographic Museum of Guinea-Bissau, the director Leonardo Cardoso, reinforced the importance of the collaboration between similar international and Guinea-Bissauan institutions to promote "cultural exchange between our countries» (Cardoso 1989, 71). He recalled that the museum had inherited:

[...] practically nothing from the Museum of Portuguese Guinea, whose activities ended in 1974, when powers were transferred to the newly created state of GuineaBissau. Not only were political powers transferred, but also the management of Colonial Heritage including the Museum itself. (Cardoso 1989, 71)

At that time, as he writes «(...) some collections and pieces in the Museum were diverted» and «(...) part of the collection reached the extinct INIC [National Institute for Scientific Research] from which an extremely small amount [was] recovered for the current Museum» (Cardoso 1989, 72).

For Cardoso «the fact that the collections in foreign hands have disappeared does not mean that no attention has been paid to safeguarding cultural values» (Cardoso 1989, 72 ), arguing that «[t] he need to study, collect, preserve and disseminate the culture of the various ethnic groups of Guinea Bissau led in 1985 to the creation of a museum project, under the tutelage of the General Directorate of Culture (...) called the National Museum Installation Commission» (Cardoso 1989, 73). The creation of the Commission was «an important and decisive milestone in Guinea Bissau's museum history, as it was a starting point for research in the field. The image of the future museum as a mirror of Guinea-Bissau's vast cultural heritage has begun to be conceived» (Cardoso 1989, 73).

In the third meeting organized by ICOM in partnership with the Secretary of State for Culture of Guinea-Bissau, in Bissau during 1991, the then Secretary of State for Social Affairs, Alexandre Furtado, referred to the ethnic-cultural diversity of Guinea-Bissau as «a solid foundation for the construction of the Guinean nation» underlining the «need to preserve the national cultural heritage [promoting] cultural development at the service of the transformation of Guinean society and in confluence with new cultural values» (Furtado 1991, 7-8). At the next meeting, in Macau in 1994, the director of MEN, Leonardo Cardoso, pointed out that Guinea-Bissau: 
[...] still lacks legislation on the defence and safeguarding of the historical and cultural heritage, even though the text of the Constitution of the Republic states that the State defends the Cultural Heritage of the People whose value must serve progress and the safeguarding of human dignity. (Cardoso 1994, 33)

\section{concept of a European-oriented colonial museum:}

The commitment was therefore to show the evolution and dynamics of activities that reflect the economic, social and cultural life of ethnic groups in Guinea-Bissau. A museum where people could appreciate objects not only old, antique or considered authentic. For us, these concepts have long been outdated, and therefore the concerns were to dignify our cultural identity by showing what is common to us and at the same time what differs us from others. It means showing all our values, the fruit of our creation and activity over time. (...) Contrary to what was and still is to some extent the concern of certain museums and collectors, that is, to have in their collection objects already used in socio-cultural manifestations, objects considered authentic, unique and very often plundered, we understand that these lose a great part of their value once they are out of context, and therefore cease to exercise their function. (Cardoso 1994, 34)

He also highlighted some important topics for reflection:

Still on the concept of the unique, authentic, we would like to refer to the Nalu cult objects, one of which is the Ninte Kamatchol used in initiation and funeral ceremonies and acquiring a sacred value. The Nalus live predominantly in the south of the country, (...) This geographical disposition makes it necessary to have several "Nintes" according to the different groups. Logically, there could not be a single object for the whole ethnic group, which, as we have seen, is scattered over several areas. Now we ask, which object is the most authentic? Another important factor to consider is that the objects are made of wood, so they are susceptible to being attacked by fungi, termites and other agents causing their physical deterioration. In this case the object is replaced by another object, which immediately performs the same functions, making the precedent a simple object without any validity. Should the unique concept prevail in this case? Is it this replaced, deteriorated, old, out of context object that is of interest to museums? (Cardoso 1994, 34)

The main question posed by Cardoso is then where does the value of African objects lie? According to him, value exists while the object serves a function that inserts it into a practice and assigns it a specific purpose. It seems relevant to compare the thoughts of the Angolan writer Henrique Abranches with those of Guinean museologist Leonardo Cardoso. While Abranches defends heritage as a static entity made to be preserved inside an institution, Cardoso recognizes its ephemeral, life-based character.

The National Ethnographic Museum collections are divided into sculpture, weaving, basketry and pottery. As Cardoso states, the constitution of these collections was based in:

[...] the making of objects must respect the basic traditional techniques, of course, always admitting new elements; the objects must be made by individuals belonging to the caste that traditionally makes the objects in question and in the making of the objects, materials traditionally known and used were used. (Cardoso 1994, 34)

In 1999, the Museum was occupied by the Senegalese military who came to support President Nino Vieira's troops. As described by Victorine Lopes Soumah, former museum employee «The collections were either totally missing or reduced to a minimum. The documentation was missing in its entirety and the furniture was destroyed» (Soumah 2000, 131). In 2000, the documentation and the museum pieces 
existing in the National Ethnographic Museum were in very bad condition because the Museum didn't have a "(...) a building or the indispensable materials for this work» (Soumah 2000,132). Through a project carried out with the Museum between 2012 and 2019 and the testimony of the current director Albano Mendes, it was possible to acknowledge that the institution returned to its original facilities in Bairro da Ajuda in Bissau between 2001 and 2009, and that the government decided that the museum would reopen in 2010 in the building that housed the Directorate General of Culture, located in the central Praça dos Heróis Nacionais (Mendes, Sarró and Temudo 2018). This last building occupied by the Museum served as the headquarters of the Museum of Portuguese Guinea in colonial times (Mendes, Sarró and Temudo 2018). This curatorial project carried out by a group of international researchers aimed to recover the history of this institution and contributed to another reopening of the National Ethnographic Museum of Guinea-Bissau. ${ }^{6}$ Since 2020, the museum has closed again due, not only to the global pandemic, but also to the general political, social and economic instability experienced in the country that transformed the Museum building into the current premises of the Presidential Palace. ${ }^{7}$ The National Ethnographic Museum of GuineaBissau opens, closes, and reopens at different times and places, and its history is always being reinterpreted and rewritten.

\section{Final notes}

47 The resistance to the movement of restitution is commonly justified by the putative lack of safeguard resources and the dependence on international cooperation programmes encountered by non-Western countries (Makuvasa 2002; Basu 2008; Kusimba and Klehm 2013). Thus, maybe we can make some changes by standing with what Homi Bhabha reminds us: to recognize that we live in a time where «it is in the emergence of the interstices - the overlap and displacement of domains of difference that the intersubjective and collective experiences of nationness, community interest, or cultural value are negotiated» $(2004,2)$. Should we not then ask ourselves to deal with cultural heritage in the interstice between nations, promoting the breaking down of physical and cultural barriers? Paul Basu's thoughts about object diasporas - primarily based on Peffer's (2005) Africa's Diasporas of Images - analyse African objects as containers of culture and consider dispersed collections around the world as "objects in motion", a way of creating relationships between communities, generating networks of exchange that entail obligations and responsibilities. As Basu (2011) affirms, there we might see the value of maintaining objects in diasporic contexts rather than insisting on their return. A way to do this is by recognizing the entire life of the collections, their historic continuity and their "intertwined stories" (Said 1993) that allow us to go beyond geographical and ethnic boundaries and articulate different histories and cultural zones (Peffer 2005). It is important to highlight that these collections - and in this case the Guinean ones - relate to diasporic communities. They are full, not only of past memories, but also of post-memories (Hirsch 2012) that come alive through experiences of the present. A lot of work has been done with source communities (Peers and Brown 2003; Modest et al. 2019) and the question now is more related to fighting social injustice, racism and inequalities to enable the fair representation of African communities inside the museum arena. Finally, it is also important to underline that the value of objects in Africa resides in the context of their use and disappears or becomes lessened when they are enclosed within a museum. In this context, the return 
of heritage to the countries of origin must respect a non-Western view of the object to be returned, allowing it to fulfil the natural cycle of its existence.

\section{Acknowledgements}

I am grateful to my PhD advisors, Laura Castro, Eric Gable and Elsa Peralta for their inspiring comments.

\section{BIBLIOGRAFIA}

Abranches, Henrique. 1989. Identidade e Património Cultural. Porto: União dos Escritores Angolanos - Secção Estudos Contemporâneos - Edições ASA.

Abungu, Lorna. 2005. "Museums and Communities in Africa: Facing the New Challenges." Public Archaeology 4 (2-3): 151-154.

Adedze, Agbenyega. 2002. "Symbols of Triumph: IFAN and the Colonial Museum Complex in French West Africa (1938-1960).” Museum Anthropology 25 (2): 50-60.

AFRICOM (International Council of African Museums). 2010. "Documentando Acervos Africanos. Manual de Normas.” Cadernos de Sociomuseologia 13 (1): 5-75 https://revistas.ulusofona.pt/ index.php/cadernosociomuseologia/issue/view/116

Arinze, Emmanuel Nnakenyi. 1998. “African Museums: The Challenge of Change.” Museum International 50 (1): 31-37.

Basu, Paul, and Wayne Modest. 2015. Museums, Heritage and International Development. New York: Routledge.

Basu, Paul. 2008. "Confronting the Past?: Negotiating a Heritage of Conflict in Sierra Leone." Journal of Material Culture 13 (2): 233-247.

Basu, Paul. 2011. “Object Diasporas, Resourcing Communities: Sierra Leonean Collections in the Global Museumscape." Museum Anthropology 34 (1): 28-42.

Bhabha, Homi K. 2004. The Location of Culture. London: Routledge.

Botas, Ana. 2013. “As Máscaras Bigajó do Museu Nacional de Etnologia. Questões em Torno da Informatização do Inventário de Coleções.” Trabalho de Projeto para obtenção de grau de mestre em Museologia, Faculdade de Ciências Sociais e Humanas, Universidade Nova de Lisboa.

Caetano, Maria João. 2020. "Devolver Espólio dos Museus aos Países de Origem? Só Vendo 'Caso a Caso', diz Especialista.” Diário de Notícias, janeiro 28. https://www.dn.pt/cultura/devolverespolio-dos-museus-aos-paises-de-origem-so-vendo-caso-a-caso-diz-especialista-11760072.html Camacho, Clara Frayão, coord. 2021. Grupo de Projeto Museus no Futuro: Relatório Final. Lisboa: Direção-Geral do Património Cultural. http://patrimoniocultural.gov.pt/static/data/docs/ 2021/02/15/RelatorioMuseusnoFuturo.pdf

Canelas, Lucinda. 2020. "Um Inventário de Bens Culturais para pôr Portugal a Pensar Sobre a Colonização.” Jornal Público, janeiro 1. https://www.publico.pt/2020/01/31/culturaipsilon/ noticia/inventario-bens-culturais-portugal-pensar-colonizacao-1902452 
Cardoso, Leonardo. 1989. “A Museologia na Guiné-Bissau.” In Acta do II Encontro de Museus de Países e Comunidades de Língua Portuguesa: 11 a 14 de Setembro de 1989, Palácio Nacional de Mafra - Portugal, 71-75. Mafra: Comissão Nacional Portuguesa do ICOM.

Cardoso, Leonardo. 1994. “As Colecções do Museu Etnográfico da Guiné-Bissau: Política de Aquisição e Natureza." In IV Encontro de Museus de Países e Comunidades de Língua Portuguesa. Macau, 28 de Fevereiro a 3 de Março de 1994, 33-34. Macau: Comissão Portuguesa do ICOM.

Collections Trust. 2020. "Restitution and Repatriation.” Accessed 13 February 2020. https:// collectionstrust.org.uk/cultural-property-advice/restitution-and-repatriation

Declaration on the Importance and Value of Universal Museums. 2004. ICOM News 57 (1): 4.

Decree-Law n.ำ 115/2012, of 25 May, Diário da República, 1.a série, n.ำ 102 (2012): 2772-2777. Creates the General-Directorate for Cultural Heritage (Direção-Geral do Património Cultural).

Diagne, Souleymane Bachir. 2021. “The Museums Lab”. Accessed 6 August 2021. https:// themuseumslab.org/

Domingos, Nuno, and Elsa Peralta. 2013. Cidade e Império: Dinâmicas Coloniais e Reconfigurações Pós-Coloniais. Lisboa: Edições 70.

Edwards, Elizabeth, Chris Gosden, and Ruth B. Phillips, eds. 2006. Sensible Objects: Colonialism, Museums, and Material Culture. London: Routledge.

Furtado, Alexandre. 1991. "Sessão Solene de Abertura do III Encontro." In III Encontro de Museus de Países e Comunidades de Língua Portuguesa, 7-8. Bissau, Guinea-Bissau: Secretariat of State for Culture, Youth and Sports of Guinea-Bissau and the Portuguese Commission of ICOM.

German Museums Association. 2021. Guidelines for German Museums Care of Collections from Colonial Contexts. Berlin: German Museums Association. https://www.museumsbund.de/wp-content/ uploads/2021/03/mb-leitfaden-en-web.pdf

Golding, Vivien, and Wayne Modest. 2013. Museums and Communities: Curators, Collections, Collaboration. London: Bloomsbury.

Grimme, Gesa. 2020. "Systemizing Provenance Research on Objects from Colonial Contexts." Museum \& Society 18 (1): 52-65.

Henriques, Isabel Castro. 2009. A Herança Africana em Portugal. [Lisboa]: CTT Correios de Portugal Clube do Coleccionador.

Henriques, Joana Gorjão. 2016. “Uma Discussão de Há Décadas.” Jornal Público, agosto 10. https:// www.publico.pt/2016/08/10/culturaipsilon/noticia/uma-discussao-de-ha-decadas-1740297

Hickley, Catherine. 2019. "Dutch Museums Take Initiative to Repatriate Colonial-Era Artefacts." The Arts NewsPaper, March 14. https://www.theartnewspaper.com/news/dutch-museums-takeinitiative-to-repatriate-colonial-era-artefacts

Hickley, Catherine. 2020. "Arts Council England Asks for Help in Returning Looted Artefacts Held in UK Museums.” The Art Newspaper, January 14. https://www.theartnewspaper.com/news/artscouncil-england-seeks-guidelines-on-restitution-and-repatriation-for-museums

Hirsch, Marianne. 2012. The Generation of Postmemory: Writing and Visual Culture After the Holocaust. New York: Columbia University Press.

ICOM Portugal. 1989. Acta do II Encontro de Museus de Países e Comunidades de Língua Portuguesa. Mafra: Palácio de Mafra. 
ICOM Portugal. 2021. “Inquérito à Presença de Património Proveniente de Territórios NãoEuropeus nos Museus Portugueses”. https://icom-portugal.org/2021/05/29/inquerito-apresenca-de-patrimonio-proveniente-de-territorios-nao-europeus-nos-museus-portugueses/? fbclid=IwAROiqMQ

ICOM. (2004) 2017. ICOM Code of Ethics for Museums. Paris: ICOM (International Council of Museums). https://icom.museum/wp-content/uploads/2018/07/ICOM-code-En-web.pdf Jong, Ferdinand de, and Michael Rowlands. 2010. Reclaiming Heritage: Alternative Imaginaries of Memory in West Africa. Walnut Creek, California: Left Coast Press.

Karp, Ivan, and Steven Lavine. 1991. Exhibiting Cultures: The Poetics and Politics of Museum Display. Washington: Smithsonian Institution Press.

Karp, Ivan, Christine Mullen Kreamer, and Steven Levine. 1992. Museums and Communities: The Politics of Public Culture. Washington: Smithsonian Institution Press.

Karp, Ivan, Corinne A. Kratz, Lynn Szwaja, Tomás Ybarra-Frausto. 2006. Museum Frictions. Public Cultures/Global Transformations. Durham and London: Duke University Press.

Kratz, Corinne A. 2014. "Adapting and Transforming Ethnographic Exhibits: Short version for Proceedings of the Conference "The Museum in the $21^{\text {st }}$ Century Africa Beyond Africa: The Future of Cultural, Social, and Scientific Research"'. https://leading-edge.iac.gatech.edu/aaproceedings/ files/2015/12/Adapting-and-Transforming-Ethnographic-Exhibits_v2.pdf

Kusimba, Chapurukha, and Carla Klehm. 2013. "Museums and Public Archaeology in Africa." In The Oxford Handbook of African Archaeology, ed. Peter Mitchell and Paul J. Lane.

Law n.․ 107/2001, of 8 September, Diário da República, 1. ․ série-A, n.ㅇ 209 (2001): 5808-5829. Establishes the basis for cultural heritage policy and its protection and valorization regime.

Law n.ำ 30/2016, of 23 August, Diário da República, $1^{1}$ série, n.ำ 161 (2016): 2831-2833. Regime of the return of cultural goods unlawfully removed from the territory of a member state of the European Union (transposes Directive 2014/60/EU of the European Parliament and of the Council of 15 May 2014).

Law n.․ 47/2004, of 19 August, Diário da República, 1ª série-A, n.․ำ 195 (2004): 5379-5394. Approves the Framework Law of Portuguese Museums (Lei-Quadro dos Museus Portugueses).

Leite, Pedro Pereira. 2014. “Memórias Esbranquiçadas: As Heranças Africanas nos Museus de Portugal.” In Diálogos Interdisciplinares: Literaturas e Políticas Culturais, ed. Geraldo Pontes Jr., Maurício Barros de Castro and Myrian Sepúlveda dos Santos, 253-271. Rio de Janeiro: Editora da UERJ.

Lusa. 2018. Entrevista a António Pinto Ribeiro: Em Portugal "não há listagens" das obras de arte a devolver às ex-colónias, mas podem ser milhares. Separata Cultura SIC Notícias, 23 November 2018 (Reuters).

Lusa. 2019. "Museus Devem Rever Discursos e Refazer Coleções sobre o Passado Colonial.” Jornal Público, march 22. https://www.publico.pt/2019/03/22/culturaipsilon/noticia/museus-reverdiscursos-refazer-coleccoes-passado-colonial-1866497

Lusa. 2020. “'Descolonizar'. Livre Exige que Património das Ex-Colónias em Museus seja Devolvido." Jornal Económico, January 28. https://jornaleconomico.sapo.pt/noticias/livre-exigeque-patrimonio-das-ex-colonias-em-museus-portugueses-seja-devolvido-541078 
M'Bow, Amadou-Mahtar. 1978. A Plea for the restitution of an irreplaceable cultural heritage to those who created it; an appeal by Amadou-Mahtar M'Bow, Director-General of UNESCO. Paris: UNESCO. https://unesdoc.unesco.org/ark:/48223/pf0000034683

Makuvaza, Simon. 2002. “Towards a New Type of 'Ethnographic' Museum in Africa.” Paper presented at the conference High Expectations, but Low Funding: How do poor museums meet their targets? Lusaka and Livingstone, Zambia July 28 - August 2, 2002. https:// icme.mini.icom.museum/wp-content/uploads/sites/16/2019/01/ICME_2002_makuvaza.pdf Mbembe, Achille. 2020. Brutalism. Paris: La Découverte.

Mendes, Albano, Ramon Sarró, and Ana Temudo. 2018. O Museu Etnográfico Nacional da GuinéBissau: Imagens para uma História. Porto: Greca.

Modest, Wayne, Nicholas Thomas, Doris Prlić, and Claudia Augustat. 2019. Matters of Belonging: Ethnographic Museums in a Changing Europe. Leiden: Sidestone Press.

Myles, Kwasi. 1976. “Museum Development in African Countries.” Museum International 28 (4): 196-202.

NMVW. 2019. "Return of Cultural Objects: Principles and Process: Nationaal Museum van Wereldculturen 7-3-2019.” NMVW (National Museum van Wereldculturen). https:// www.tropenmuseum.nl/sites/default/files/2019-06/ NMVW\%20Return\%20of\%20Cultural\%200bjects\%20\%20Principles\%20and\%20Process.pdf

Ordinance n.․2 223/2012, of 24 July, Diário da República, 1.a série, n.. 142 (2012): 3876-3881. Determines the structure and competences of the nuclear organic units of the GeneralDirectorate for Cultural Heritage.

Peers, Laura Lynn, and Alison Brown. 2003. Museums and Source Communities: A Routledge Reader. New York: Routledge.

Peffer, John. 2005. “Africa's Diasporas of Images.” Third Text 19 (4): 339-355.

Pereira, Manuela Cantinho. 2010. “As Colecções Etnográficas Extraocidentais em Portugal: Passado, Presente e Futuro.” 7. Congresso Ibérico de Estudos Africanos, Lisboa.

Pereira, Maria Manuela Cantinho. 2005. O Museu Etnográfico da Sociedade de Geografia de Lisboa: Modernidade, Colonização e Alteridade. Lisboa: Fundação Calouste Gulbenkian and Fundação para a Ciência e a Tecnologia.

Peterson, Derek R., Kodzo Gavua, and Ciraj Rassool. 2015. The Politics of Heritage in Africa: Economies, Histories, and Infrastructures. New York: Cambridge University Press.

Resolution of the Council of Ministers n. 35/2019, of 18 February, Diário da República. 1. ${ }^{a}$ série, n.ำ 34 (2019): 1272-1274. Creates the Future Museums Project Group (Grupo de Projeto Museus no Futuro).

Said, Edward. 1993. Culture and Imperalism. New York: Knopf.

Sarr, Felwine, and Bénédicte Savoy. 2018. The Restitution of African Cultural Heritage.

Sarró, Ramon, and Ana Temudo. 2021. "The Lives and Deaths of an Ethnographic Museum: History, Violence and Curatorial Collaborations in Guinea-Bissau." Museum and Society 19: 369-381.

Schorch, Philipp. 2020. "Sensitive Heritage: Ethnographic Museums, Provenance Research, and the Potentialities of Restitutions." Museum \& Society 18 (1): 1-5. 
Silverman, Raymond. 2014. Museum as Process: Translating Local and Global Knowledges. London: Routledge.

Soumah, Victorine Lopes. 2000. “Documentação dos Objectos do Museu Etnográfico Nacional.” In $V$ Encontro Encontro de Museus de Países e Comunidades de Língua Portuguesa, 131-132. Maputo: ICOM and Departamento de Museus do Ministério da Cultura de Moçambique.

Taking Care Project. 2021. "TAKING CARE - Ethnographic and World Cultures Museums as Spaces of Care." Accessed 8 August 2021. https://takingcareproject.eu/about

The Museums Lab. 2021. "Who we Are.” Accessed 8 August 2021. https://themuseumslab.org

Towards a New Relational Ethics. France: Ministère de la Culture; Université Paris Nanterre. http:// restitutionreport2018.com/sarr_savoy_en.pdf

Tythacott, Louise, and Kostas Arvanitis. 2014. Museums and Restitution: New Practices, New Approaches. London: Routledge.

UNESCO. 1954. Final Act of the Intergovernmental Conference on the Protection of Cultural Property in the Event of Armed Conflict, The Hague, 1954. Paris: UNESCO (United Nations Educational, Scientific and Cultural Organization). https://unesdoc.unesco.org/ark:/48223/ pf0000082464

UNESCO. 1970. Convention on the Means of Prohibiting and Preventing the Illicit Import, Export and Transfer of Ownership of Cultural Property; adopted by the General Conference at its sixteenth session, Paris, 14 November 1970. Paris:. https://unesdoc.unesco.org/ark:/48223/ pf0000133378

UNESCO. 2001. Promote the Return or the Restitution of Cultural Property: (information kit). Paris: UNESCO. https://unesdoc.unesco.org/ark:/48223/pf0000139407?

$3=$ null\&queryId=c11c9f5c-645d-46b3-a245-4ebae47ad1e 5

UNIDROIT. 1995. UNIDROIT Convention on Stolen or Illegally Exported Cultural Objects. Rome: UNIDROIT (International Institute for the Unification of Private Law). https://www.unidroit.org/ english/conventions/1995culturalproperty/1995culturalproperty-e.pdf

Weber-Sinn, Kristin, and Paola Ivanov. 2020. “'Collaborative' Provenance Research - About the (Im)Possibility of Smashing Colonial Frameworks.” Museum \& Society 18 (1): 66-81.

\section{NOTAS}

1. From this section onwards all citations are translated by the author.

2. ICOM Portugal Encontro de Outono (Fall meeting) - Museus com Coleções não Europeias (Museums with Non-European Vollections), 4-5 November 2021. https://www.youtube.com/watch? $\mathrm{v}=\mathrm{htTELioeQSI}$ (accessed 16 December 2021).

3. Pinto Ribeiro takes part in the project Memoires - Filhos de Império e Pós-Memórias Europeias (Centro de Estudos Sociais da Universidade de Coimbra), a research project that aimed to analyse the memories inherited by the children of the generation that lived through the decolonisation processes in the territories dominated by Portugal, France and Belgium on the African continent. This project was funded by the European Research Council between November 2015 and October 2021. See: https://memoirs.ces.uc.pt/index.php?\&id_lingua=1 (accessed 16 December 2021).

4. Seminar Descolonizar os Museus: Isto na Prática?: https://acessocultura.org/descolonizar-osmuseus-isto-na-pratica/ (accessed 16 December 2021). 
5. This subject constitutes the theme of my ongoing Ph.D. thesis entitled: "Representational Politics of Guinean Heritage in Portuguese Museums in the Transition from Colonial to Postcolonial Period: Histories, Transits and Discourses" (REF 2020.08039.BD), funded by the Portuguese Foundation for Science and Technology (FCT).

6. The history of this museum is explored in depth in Sarró and Temudo (2021).

7. Data obtained through an informal conversation with the Museum's director, Albano Mendes, in October 2020.

\section{RESUMOS}

A questão da restituição do património cultural aos países de origem tem ocupado a recente agenda política internacional. Este artigo analisa as diferentes perspetivas a partir das quais esta questão tem sido abordada, em Portugal e no estrangeiro, nomeadamente no campo legislativo que rege as instituições do património, no campo académico e na esfera pública. Esta análise visa compreender os atuais significados atribuídos ao património africano nos museus e outras instituições do património ocidental, bem como nos países de origem. Como estudo de caso, apresenta a realidade patrimonial da Guiné-Bissau e indica diferentes possibilidades para uma representação justa das comunidades da diáspora de hoje, com o objetivo de contribuir para um debate informado sobre o impacto do retorno e da restituição do património africano para os seus países de origem nas futuras representações da cultura e identidade africanas à escala global.

The restitution of cultural heritage to countries of origin has occupied the recent international political agenda. This article analyses the different perspectives from which this question has been approached, in Portugal and abroad, namely in the legislative field governing heritage institutions, in the academic field and in the public sphere. This analysis aims to understand the current meanings attributed to African heritage in museums and other Western heritage institutions, as well as in the countries of origin. As a case study it presents the heritage reality of Guinea-Bissau and indicates different possibilities for a fair representation of today's diasporic communities, aiming to contribute to an informed debate on the impact of the return and relocation of African heritage to their countries of origin on future representations of African culture and identity on a global scale.

\section{ÍNDICE}

Keywords: cultural policies and museums, postcolonialism, restitution of cultural property, National Ethnographic Museum of Guinea-Bissau, provenance research

Palavras-chave: políticas culturais e museus, pós-colonialismo, restituição de bens culturais, Museu Etnográfico Nacional da Guiné-Bissau, pesquisa de procedência de objetos 


\section{AUTOR}

\section{ANA TEMUDO}

Has a degree in Fine Arts, a postgraduation in Artistic Studies (Faculdade de Belas-Artes, Universidade do Porto) and a master in Museology (Faculdade de Letras, Universidade do Porto). Presently she is a PhD candidate in Heritage Studies, at the Universidade Católica Portuguesa, School of Arts, Research Centre for Science and Technology of the Arts (CITAR). Temudo has collaborated in several museum research-based projects that promote interdisciplinarity among the humanities, arts and social sciences. Her doctoral thesis "Representational Politics of Guinean Heritage in Portuguese Museums in the Transition from Colonial to Postcolonial Period: Histories, Transits and Discourses" is funded by the Portuguese Foundation for Science and Technology (FCT) with an individual scholarship.

Centro de Investigação em Ciência e Tecnologia das Artes (CITAR), Rua de Diogo Botelho, 1327, 4169-005 Porto, Portugal, anatglima@gmail.com 